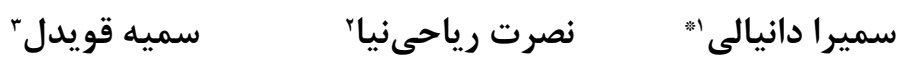

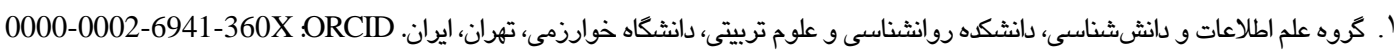

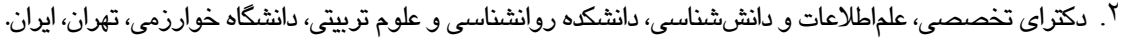

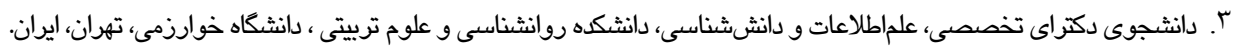

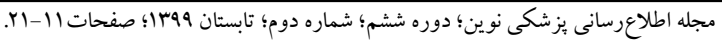

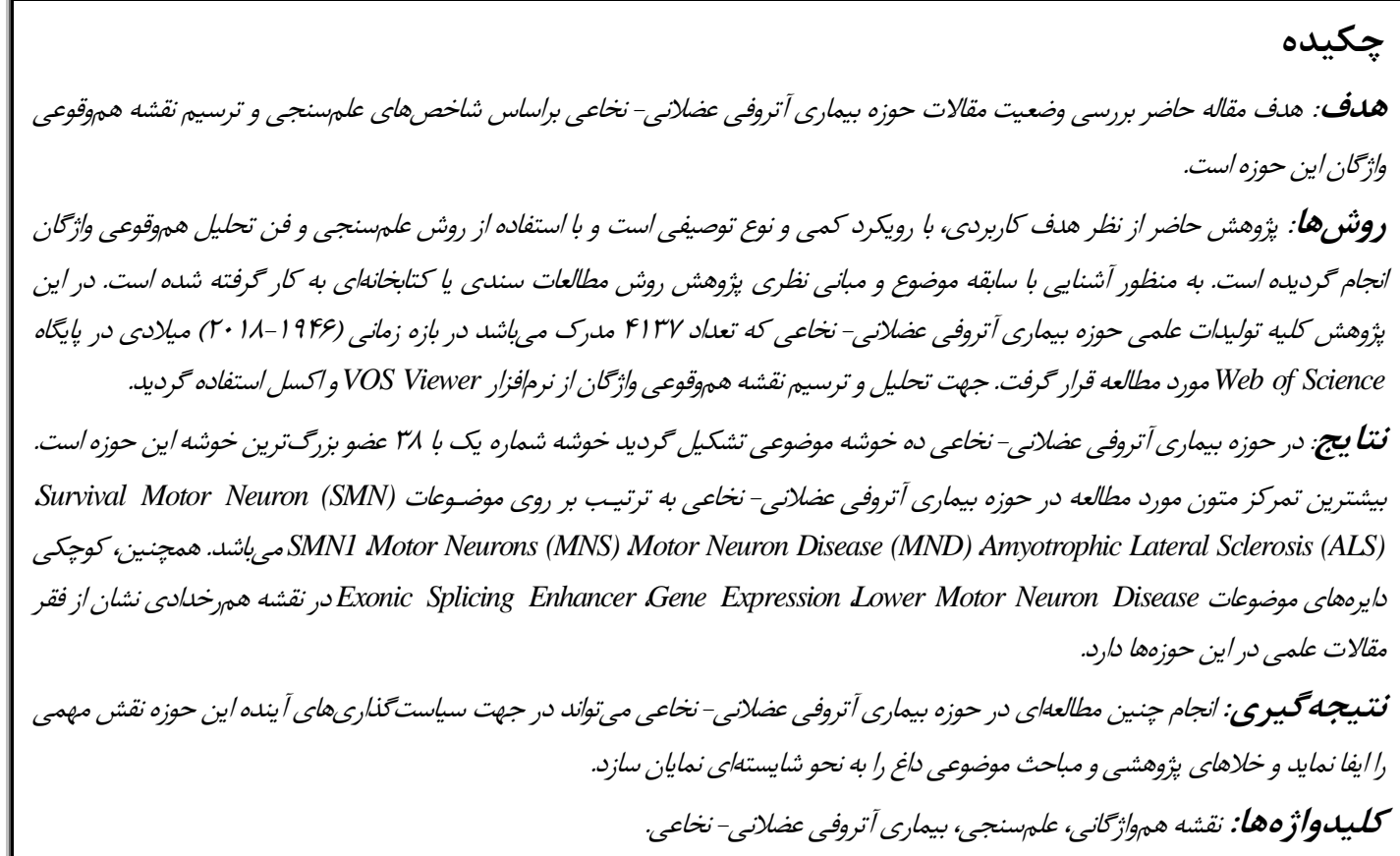

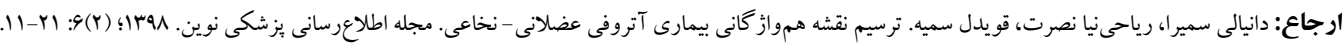

مفهومى يك حوزه بلهادگى مصورسازى مىشود. از نظر مفهومى تحليل همرخدادى وازٔكان، روش مناسبى براى كشف ارتباطات حوزههاى

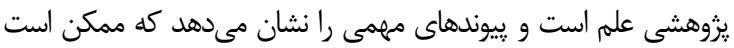
كشف آنها به روشهاى ديخر مشكل باشد. روش تحليل همرخدادى وارگًان، مىتواند به عنوان ابزارى قدرتمند، امكان تعقيب تحولات ساختارى و تكامل شبكه ادراكى و اجتماعى را ميسر كند [1].] با استفاده از روش همرخدادى وازّكان همحنين، مىتوان موضوعات

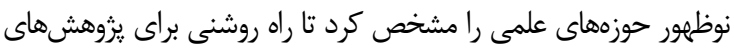

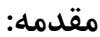
ترسيم ساختار علم براساس روشهاى مختلفى صورت مى گيرد كه

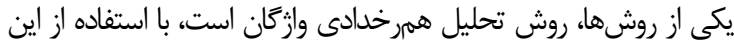
روش مىتوان به بررسى و شناسايى روابط مفهومى ميان متون حوزه0هاى علمى يرداخت و از آن براى سياستكذارى كلى و انتخاب موضوع

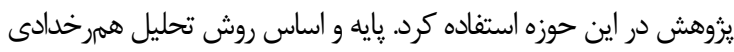
وازگًان اين انديشه است كه همرخدادى وازًّان مىتواند مفهوم اسناد را توصيف كند. با اندازمكيرى ميزان ارتباط اين همرخدادى وازثان، نماى 
هدف از تهيه نقشه علم، شناسايى نقاطى از دانش است كه به

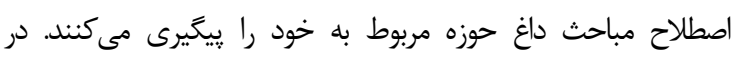
حوزهاى داغ فعاليتهاى يروهشى بيشترى صورت مى گيرد. تحليـل هموازگكانى، روش مناسـبى بـراى كشـف ارتباطـات يزوهشىهاى حـوزه

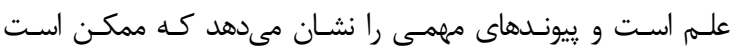
كشـف آنها بهروشهاى ديخـر مشكل باشد. روش تحليـل هـهوازَّانى، مىتواند به عنوان ابزارى قدرتمند، تحـولات و تكامـلى سـاختار شبكه

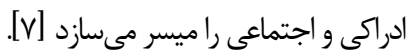
علمسنجى، حوزهاى بينرشتهاى است كه متخصصان جامعلشناسى، رئى اقتصاد، تاريخ، كتابدارى و اطلاعرسانى، فيزيك، رياضى، مديران و مسئولان سياست كذارى و نظاير آن، با آن سروكار دارند [^]. بنابراين به ميه دليل اهميتى كه ترسيم ساختار علم در جهت هدفمند كردن يزوهشهاى آتى دارد، انجام جنين مطالعهاى در حوزه بيمارى آتروفى عضلانى - نخاعى مىتواند در جهت سياست گذارىهاى آينده اين حوزه نقش مهمى را ايفا نمايد و خلأهاى يزوهشى و مباحث موضوعى داغ را به نحو شايستهاى نمايان سازد. نقشههاى علمى با استفاده از روشهاى مختلفى ترسيم مىشود كه همرخدادى وازگًان يكى از آنهاست. منظور

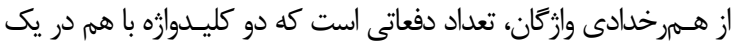
مدرك مىآيند. روش همرخدادى وازگكان اولين بـار بـراى ترسـيم

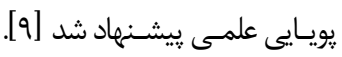
مهدىزاده و همكاران در يروهشى با عنوان الترسيم نقشه علم

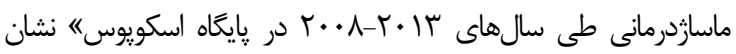

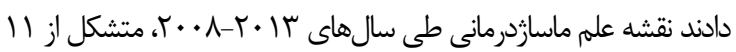
موضوع اصلى است كه عبارت انداز از ا - موضوعهاى عام و مهمم (مثل طبمكمل و جايكزين، طبسنتى، سرطان، افسردىى و اضطراب، موزيك درمانى، رثيمهاى غذايى و ...) r- قلب و عروق r- داروها و عصارههاى كَياهى F - جسم، عضلهها، بافتها و مفاصل ه- نوزادان، كودكان و زنان

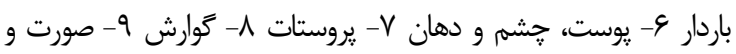

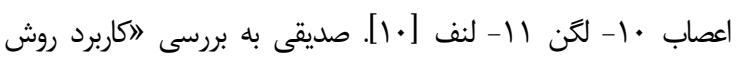
تحليل همايندى وازگان در ترسيم ساختار حوزهاى اطلاعسنجى" يرداختند. براساس نقشههاى حاصل شده از تحليل مدارك مورد مطالعه، مفاهيمى از قبيل علم اطلاعات، كتابخانه، تحليل كتابسنجى، نوآورى و متنكاوى از جمله يركاربردترين موضوعات در حوزه اطلاعسنجى در سطح بينالملى بشمار مىروند. برخى از وازهها نظير الحليل كتابسنجى" در تمامى سالهاى موردمطالعه حضور دارند، درحالى كه برخى ديكر در طول زمان نايديد مىشوند. مفاهيم جديد به عنوان
آينده باشد. ترسيم ساختار علم، اسناد مكتوب بسيار بارزشى در رابطه با

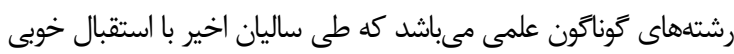
از سوى يزوهشكران مواجه بوده است. بيمارى آتروفى عضلانى - نخاعى (SMA) Spinal Muscular Atrophy مغلوب (AR) Autosomal Recessive مىباشد كـه در اثر تخريـب نورونهاى حركتى در سلولهاى شاخ قدامى نخـاع و پايه مغز يديدار مىشود. ميـزان شـيوع ايـن بيمـارى الدر .. . .اتولد و فراوانى ناقلين

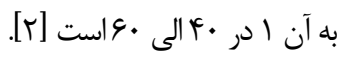
در اين بيمارى نورونهاى حركتى شاخ قدامى نخاع و پايه مغز

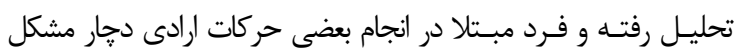

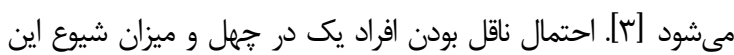
بيمـارى يـك در شش تا ده هزار تولد زنده است [Y] زن مربـوط بــه بيمـارى آتروفى عضلانى - نخاعى در سـال 1990 Survival Motor) SMN تشخيص داده شـد ايسن زن كـه ناميده مىشود، در اكثـر ايـن بيمـاران دجـار حذفشدگى (Neuron

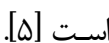
براساس علاتم بالينى، بيمارى اساماى به جهار زروه عمده تقسيمبندى مى گردد. تيّ يك بيمارى SMA، از نظر عارضه بـالينى شـديدترين نوع بوده و سن بروز بيمارى از زمان تولد تا و ماهكى اسـت. نوزادان مبتلا به اين نوع بيمارى، بدون محافظ قادر به نشستن نبوده و

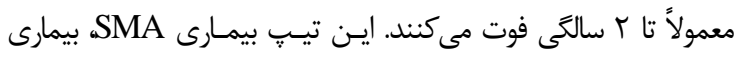

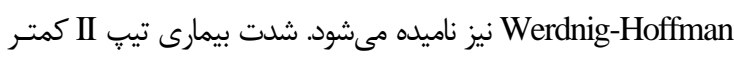
از تيـٍ يـك اسـت. سـن بـروز بيمارى در اين مبتلايان بين 9 تا عال مـاهكى بـوده و نـوزادان مبتلا قادر به نشستن بوده ولى بدون كمك قادر

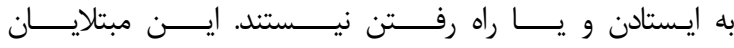
عمومــــاً بعد از Y سالكَى فوت مى كنند. سن بروز تيٍ III بيمارى بعـد از 11 مـاهكَى اسـت. در ايـن افراد هييرتروفى عضلانى سـاق يـا و رعشه دستها و هــمجنــين عـدم تعــادل در راه رفــن (تلوتلو

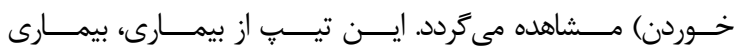
SMA بيمارى Kugelberg-Welander در بزرگسالى بـروز مى كند (بعـد از ســين • ب سـالكَ). در ايــن مبتلايــان ضــف عـضلاتى در ماهيحههاى بازو و ران و هييرتروفى بـى كاذب ماهيجههاى سـاق ڤا مـشاهده مىشود. علاثم بـالينى بيمـارى

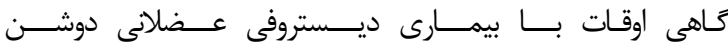
(Duchenne Muscular Dystrophy) DMD 
ضمناً خوشه علمسنجى به عنوان يكى از مهمترين مباحث اين حوزه مطرح شد [10].

مظفرى و مرادى در يزوهشى كه با استفاده از روش تحليل

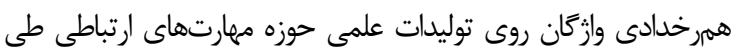

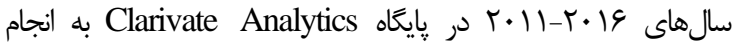
رساندند. طبق قانون Bradford's 119 كليدوازه به عنوان كليدوازههاى هسته شناسايى گرديد و كليدوازههاى آموزش، اطلاعات و تكنولوزىهاى ارتباطى با بيشترين فراوانى كاربردىترين كليدوازهها معرفى شدند. با ترسيم نقشه علم حوزه مهارتهاى ارتباطى براساس تحليل همرخدادى بـى برين

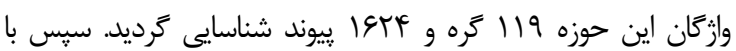
استفاده از نتايج حاصل از تجزيهوتحليل دادهها و ترسيم نقشههاى موضوعى مشخص كرديد. بيشترين تمركز حوزه موردبررسى بر روى

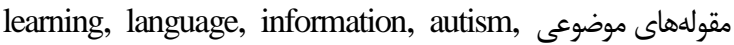
teamwork

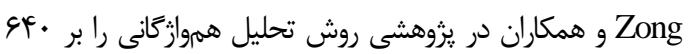
رساله دكترى به كار گرفتند كه در رشته علوم كتابدارى و اطلاعرسانى در جين انجام شده بودند. نتايج تحليل آنها به شناسايى ها خوشه از قبيل منابع اطلاعاتى، هستىشناسىها، دولت الكترونيكى، مديريت دانش، كتابخانهاى رقومى، بازيابى اطلاعات، شبكه اجتماعى، ارزيابى علوم

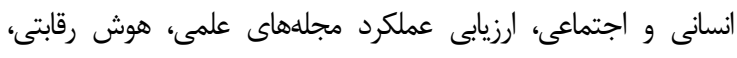
مديريت كتابخانهها، كتابسنجى، علمسنجى و مديريت اطلاعات منجر شد كه بسيارى از آنها نابالغ بودند و معدودى از جمله منابع اطلاعاتى، ميك، دولت الكترونيك، كتابخانهاى رقومى و مديريت دانش خوش توسعه و

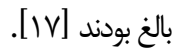
Xie به بررسى نقاط داغ يزوهشى در حوزه خطرات محيطزيست و اكولوزيك در جين با استفاده از تجزيهوتحليل همايندى كلمات كليدى يرداخت. نقاط داغ يزوهشى را به ينج دسته تقسيم كرد كه شامل ارزيابى خطر زيستمحيطى در فلزات سنگين در گلولاى يايين، ارزيابى خطر

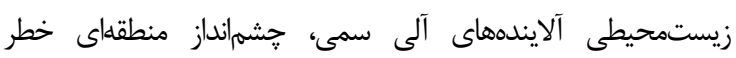
زيستمحيطى، حوادث ايمنى محيطزيست و مديريت ريسك است

و و همكاران به ارزيابى جرخه حيات يُرداختند. موضوعات هسته در اين يروهش عبارتاند از: كازهاى كلخانهاى، اثرات زيستمحيطى، مصرف انرزى، سوختهاى زيستى، محيطزيست صنعتى، ارزيابى اقتصادى، انتشار كربن، دىاكسيد كربن، توسعه بايدار، تغيير اقليم، بازيافت
بازتركيبى از وازمهاى موجود و در تعامل با تحولات و فناورىهاى جديد يديد مى آيند [a].

احمدى و كوكبى از روش تحليل همايندى وازًان براى شناخت يبيوند و مرز بين دو حوزه مديريت اطلاعات و مديريت استفاده كردند. نتيجه نشان داد مديريت دانش حوزاى است كه تا حدودى زمينه فعاليت رشته مديريت با تمام گرايشهاى آن است و مديريت اطلاعات نيز زمينه مطالعاتى رشتههايى، همجِون مدارك يزشكى و علم اطلاعات هست. همجنين رشته علم اطلاعات مرز مشتركى براى هر دو حوزه محسوب مىشود. استخراج كليدوازمهاى مستند شده براى هر دو حوزه از ديكر نتايج اين يزوهش است [11]]

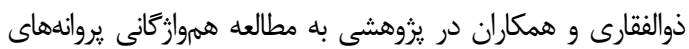
ثبت اختراع مرتبط با فناورى برق ربات زيرسطحى خودكار زمينههاى موضوعى مربوط به اين فناورى را شناسايى نمود. يافتهها نشان داد كه موضوعات (سيستم ارتباطات، سيخنالهاى صوتى، انتقال سيخنال، ناوبرى، سيستم كنترل، آنت، كاتد، سيستمهاى سونار، تصاوير سونار، سيستم نيرو، سنسورها، سيستمهاى هماهنگىى، سيستم ييرانش و منبع تغذيه) از مركزىترين موضوعات حوزه برق ربات زيرسطحى خودكار هستند [IT] مكىز اده و همكاران به ترسيم نقشه علمى و تحليل موضوعى حوزه درمان افسردگى يرداختند و نشان دادند كه الدارودرمانى و روانشناسى" فعالترين زمينهاى يزوهشى است؛ و زمينههاى موضوعى "إيبندى به درمان" و الفكار خودكشى" در رتبه اول و دوم زمينههاى نوظهور در اين حوزه قرار دارند. همجنين براساس نقشههاى ترسيمشده با استفاده از شاخصهاى مركزيت نزديكى و بينابينى بيشترين ارزش به زمينههاى موضوعى "روانشناسى، دارودرمانى و عوامل ضدافسردگى" اختصاص دارد

خادمى و حيدرى در يزوهشى تحت عنوان الرسيم ساختار

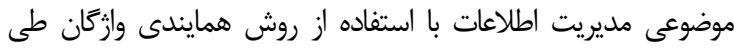

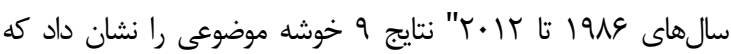
شامل مديريت اطلاعات، بيوانفورماتيك، مديريت عملكرد، اطلاعات، داده، مديريت اطلاعات سلامت، سيستمهاى اطلاعاتى، سلامت الكترونيك و سازماندهى دانش است [1 [1 [1]. مصطفوى و همكاران به شناسايى ساختار محتوايى مطالعات علم اطلاعات و دانششناسى با استفاده از تحليل همرخدادى وازٔكان در يايكاه وبكاه علم يرداختند. نتايج اين يروهش گوياى پديدار شدن مهمترين

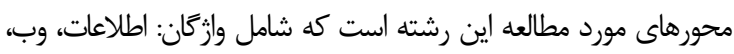
يروهش، تحليل استنادى، دانش، كتابخانه، مجلات و فناورى مىباشد. 
هدف اصلى يروهش حاضـر، ترسيم و تحليل نقشـه علمى حـوزه بيمارى آتروفى عضلاتى- نخاعى در يايگاه Web of Science در بازه

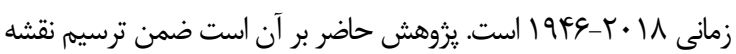
همرخدادى وازٔان بيمارى آتروفى عضلانى- نخاعى، اصطلاحاتى كه بيشترين ميزان همرخدادى وازَّان را دارا مىباشند و خوشههاى موضوعى شكل گرفته در اين حوزه را مشخص نمايد.

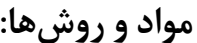

يروهش حاضر از نظر هدف كاربردى است و به روش علمسنجى و تحليل همايندى وارگًان انجام كرديده است. به منظور آشنايى با سابقه موضوع و مبانى نظرى يزوهش روش مطالعات سندى يا كتابخانهاى به كار گرفته شده است. تحليل همايندى وازًّان بدين معنى ست كه كاه دو عنصر در يك مدرك با يكديگر ظاهر مىشوند كه ارتباط بيشترى با هم دارند. اصل نقشه علم نيز بر اين نكته دلات دارد كه دو عنصرى كه باهم

ارتباط بيشترى دارند در نقشه، كنار همديكر قرار مى گيرند [سץ]. در اين يروهش كليه توليدات علمى قلمرو بيمارى آتروفى عضلانى -

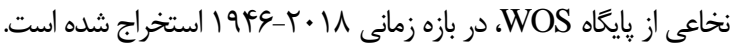
در مرحله اول، براى مشخص كردن كليدوازمهاى اصلى و همجنين يكدستسازى وازَٔان مرتبط با بيمارى آتروفى عضلانى- نخاعى، از سرعنوان هاى موضوعى يزشكى (Mesh) استفاده شد. در اين روش ابتدا اصطلاحات همارز مورد جستجو قرار گرفته سيس

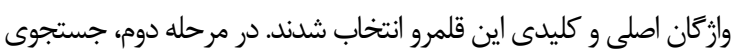
كليدوازههاى تعيين شده در يايخاه WOS انجام شد. از آنجا كه پايكاه مذكور يكى از مهمترين بايخاههاى اطلاعاتى علمى دنياست كه توسط موسسه اطلاعات علمى طراحى شده است، بدين منظور انتخاب شد.

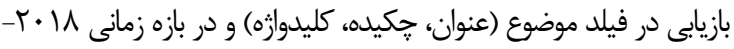

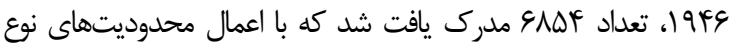
مدرك (مقاله) و زبان (انكليسى) تعداد مدارك به FTIV مورد كاهش بيدا كرد كه جزئيات اين جستجو در جدول آ آورده شده است.

جدول ا- نتايج جستجو به همراه اعمال محدوديتها در بازه زمانى

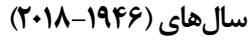

\begin{tabular}{|c|c|c|}
\hline تعداد نهايیى مدارك & تعداداوليه مدارى & كليدواثه \\
\hline 4.94 & $9 \Delta 9$. & Spinal Muscular Atrophy \\
\hline 119 & rit & Spinal Muscular Atrophies \\
\hline 4 & $\Delta T$ & Spinal Amyotrophy \\
\hline FTIV & GNDF & مجمع \\
\hline
\end{tabular}

Chen و همكاران با تهيئ ماتريس همرخدادى كليدوازمهاى مقالات 19 مجلهُ هسته و با در نظرگرفتن رخداد كليدوازهها در انتشارات هر مؤسسه، در مقايسه با ساير مؤسسات، به شناسايى موضوعات مورد علاقه ᄉ مؤسسه يروهشى معروف اين كشور و خوشابندى موضوعات يراختند. نتايج حاصل از اين يزوهش نشان داد كه جه موضوعاتى در هر مؤسسه بيشتر موردتوجه قرار كرفته است [. Konstantinidis و همكاران در يروهشى بـا عنـوان "لبررسى روند اينترنت اشيا در سلامت با استفاده از كتابسنجى و دادهاوى" انجام دادند. يزوهش آنها به بررسى رونـد

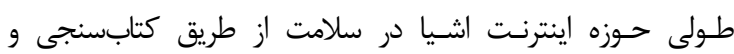

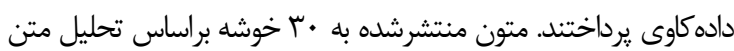

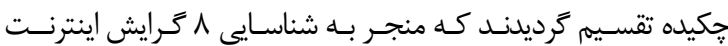

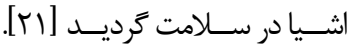
Khasseh طلاعاتى يرداختند. در اين يروهش كه با استفاده از تحليل همرخدادى وازًٔان و تحليل شبكههاى اجتماعى انجام شد، 11 خوشه شكل كرفته عبارتاند از شاخصها و پايخاههاى علمسنجى، تحليل استنادى و پايه نظرى، جامعهشناسى علم، مقالات مربوط به رتبهبندى دانشعامها، مجلات و غيره، مصورسازى و بازيابى اطلاعات، ترسيم ساختار علم، وبسنجى، رارتباطات صنعت- دانشَاه- دولت، فن سنجى (نوآورى و اختراع)، تحليل شبكه و همكارىهاى علمى در دانشگاها كه بزرگترين آنها خوشه "اتحليل استنادى و پايه نظرى" بود. مهمترين و تأثيركذارترين خوشهها

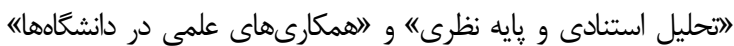

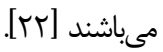
مرور بيشينه يزوهش نشان داد كـه تحليـل همرخدادى وارَّان روشى مناسـب بـراى ترسـيم سـاختار علـم و ترسـيم نقشههاى موضـوعى اسـت و در حوزههاى گَونـاتون از ايـن روش بـراى

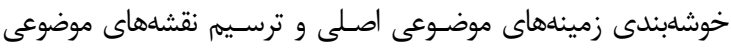
استفاده و كارهاى تحليلى مناسـبى نيـز انجام شده است. همجنين بررسى يـروهشهـاى ييشـين نشان داد كه تاكنون يزوهش مستقلى در

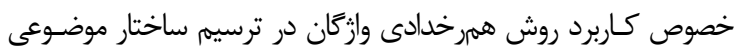
حـوزه بيمارى زنتيكى آتروفى عضلانى- نخاعى انجـام نشده است.

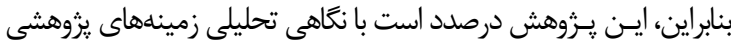
اين حوزه را به كمك روش همرخدادى وازگًان شناسايى و ترسـيم كنـد و ميزان كارآيى اين روش را در شناسايى و تعيـين اولويـتهـاى علمى و يزوهشى مشخص نمايد. 


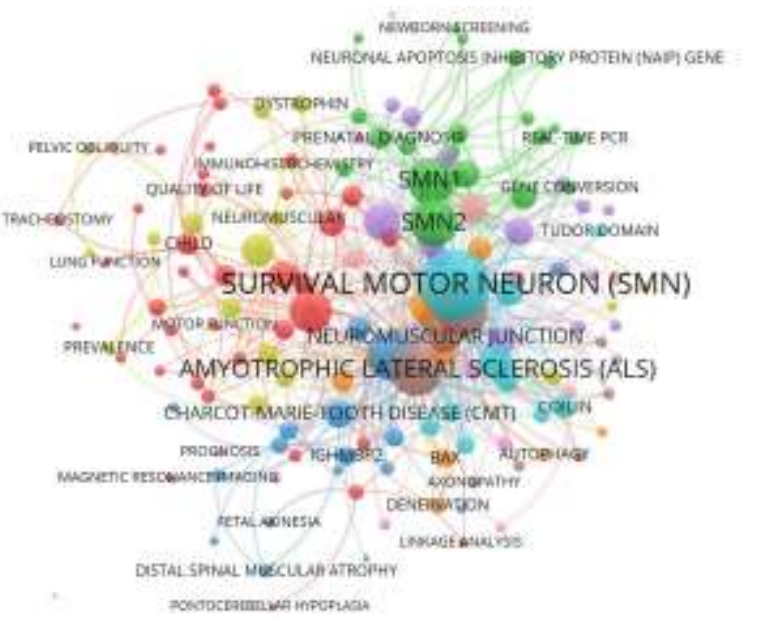

شكل ا - نقشه برجسبى همرخدادى وازَّان حوزه بيمارى آتروفى عضلانى - نخاعى همرديى

در جدول شماره r ده وازه با بيشترين ميزان همرخدادى در حوزه بيمارى آتروفى عضلایى - نخاعى مشخص است.

جدول r - ده وازه با بيشترين ميزان همرخدادى در حوزه بيمارى آتروفى عضلانى - نخاعى

\begin{tabular}{|c|c|}
\hline رخداد & اصطلاح \\
\hline TAT & Survival Motor Neuron (SMN) \\
\hline irr & Amyotrophic Lateral Sclerosis (ALS) \\
\hline 110 & Motor Neuron Disease (MND) \\
\hline 110 & Motor Neurons (MNS) \\
\hline at & SMN1 \\
\hline$\Lambda \Delta$ & Neuromuscular Disease \\
\hline$\wedge$. & SMN2 \\
\hline$\Delta T$ & Apoptosis \\
\hline Q1 & Survival Motor Neuron Gene \\
\hline ev & Duchenne Muscular Dystrophy \\
\hline
\end{tabular}

تجزيه و تحليل نتايج مربوط به تحليل هم وازكانى خوشههاى موضوعى شكل گرفته در حوزه بيمارى آتروفى عضلانى-نخاعى منجر به شكل گيرى • ا خوشه موضوعى شده است كه در ادامه به بررسى آنها يرداخته مىشود.

خوشه شماره يك حوزه SMA بزرگترين خوشه محسوب مىشود و شامل ^ץ اصطلاح مىباشد. اين اصطلاحات به ترتيب وزن عبارتاند از: Neuromuscular Neuromuscular Disease

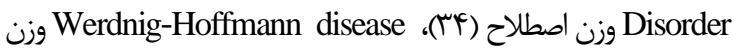
اصطلاح (•r)، Clinical Trial وزن اصطلاح (rآ)، Child وزن اصطلاح
در مرحله سوم، از طريق جستجوى همزمان كليدوازههاى تعيين شده و اعمال محدوديتهاى مذكور، تعداد FITV مدرك مورد مطالعه قرار كرفتند. در نهايت براى انجام تحليلهاى علمسنجى از نرمافزار Excel Viewer

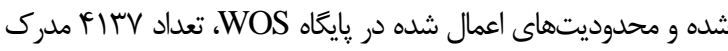

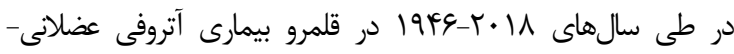
نخاعى مورد مطالعه قرار كرفتند.

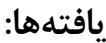

در شكل ا نقشه برجسبى همرخدادى وازگًان حوزه بيمارى آتروفى

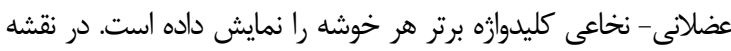
برجسبى شبكه كليدوازههاى هر مفهوم به صورت دايره رنكى نمايش داده

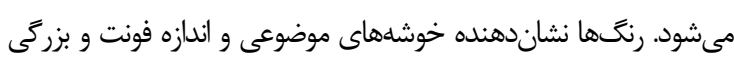
دايره نشاندهنده وزن آن مفهوم يا به عبارت ديخر تعداد تكرار يا هموقوعى آن مفهوم است. در هر خوشه، مفاهيم داراى بيشترين تكرار يا به عبارتى داراى وزن بيشتر، با دايره بزرگترى نمايش داده شده است و مفهوم اصلى خوشه در نظر گرفته مىشود؛ بنابراين موضوعات... مفاهيم اصلى خوشهها محسوب مىشود. ارتباط موضوعى و فاصله موجوديتها در نقشه رابطه مستقيم دارند؛ بنابراين هرجه دو موجوديت از هم دورتر باشند، مشابهت موضوعى آنها كمتر خواهد بود. در حوزه بيمارى آتروفى عضلانى- نخاعى ده خوشه موضوعى تشكيل گرديد. بيشترين ميزان همرخدادى وازگًان در حوزه بيمارى Survival Motor آتروفى عضلانى- نخاعى مربوط به موضوعات Amyotrophic Lateral Sclerosis (ALS) ،Neuron (SMN) פMotor Neurons (MNS) Motor Neuron Disease (MND) مىباشد. ايسن بـدان جهت است كه آنها داراى دايره بزرگترى SMN1 نسبت به بقيه مفاهيم هستند.

همجنين، كوجكى دايرههاى Lower Motor Neuron Disease، Exonic Splicing Enhancer, Gene Expression همرخدادى نشان از فقر مقالات علمى در اين حوزهها دارد. مفاهيم در سطح نقشه از يراكندكى نسبتاً خوبى برخوردارند. 
Newborn Screening (l) (1) (1) (1)

خوشه شماره r شامل M M اصطلاح مىباشد. اين اصطلاحات به ترتيب وزن عبارتاند از: Motor Neuron Disease (MND) وزن اصطلاح (DV)، (CMT)

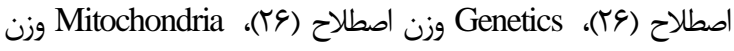
اصطلاح (IV)، Peripheral Neuropathy وزن اصطلاح (19)،

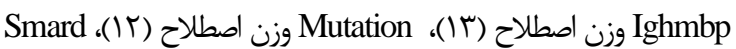

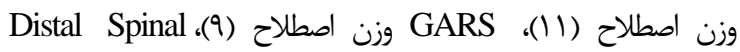
Muscular Atrophy اصطلاح (V)، Tlycyl-Trna Synthetase وزن اصطلاح (؟)، Trpv4 وزن اصطلاح (9)، Fetal Akinesia وزن اصطلاح (؟)، Dync1h وزن اصطلاح (ه)، Electrophysiology وزن اصطلاح (ه)، Dynein وزن اصطلاح (i). (l) خوشه شماره f شامل 1 ا اصطلاح مىباشد. اين اصطلاحات به ترتيب وزن عبارتاند از: Duchenne Muscular Dystrophy وزن اصطلاح (YY)، Muscular Dystrophy وزن اصطلاح (YY)، Myopathy Scoliosis Dystrophin وزن اصطلاح (س)، Becker Muscular Dystrophy وزن اصطلاح (1)، Neuromuscular وزن اصطلاح (1)، TDP-43

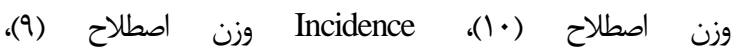
Immunohistochemistry اصطلاح (N)، Ubiquitin وزن اصطلاح (V)، Neuromuscular Scoliosis خوشه شماره ه شامل ها اصطلاح مىباشد. اين اصطلاحات به ترتيب وزن عبارتاند از: Alternative Splicing وزن اصطلاح (Y)، Gene، Antisense Oligonucleotide (ASO) Therapy PRE-Mrna Splicing اصطلاح (1) (1) Exon Inclusion وزن اصطلاح (Ir)، Myotonic Dystrophy وزن اصطلاح (1) Neuroprotection اصطلاح (1)، Exonic Splicing Enhancer وزن اصطلاح (•)، Gene، وزن اصطلاح (9)، Brain وزن اصطلاح (9) A1
(9) (1)، Non-Invasive Ventilation وزن اصطلاح (IN)، Electromyography وزن اصطلاح (IV)، وزن اصطلاح (IVenotype Anterior Horn Cell وزن اصطلاح (1) Valproic Acid (1) وزن اصطلاح (Infant (1) وزن اصطلاح (I) (1)، Arthrogryposis وزن

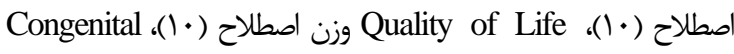
Myopathy ( • ()، Muscle Weakness وزن اصطلاح (•)، (1)، Palliative Care وزن اصطلاح (9)، Respiratory Insufficiency وزن اصطلاح (9)، Mechanical، Respiratory Insufficiency Ventilation Pregnancy Kugelberg-Welander Disease وزن اصطلاح (Vehabilitation وزن)، Muscle، (V) ولاح الصناح Biopsy اصطلاح (؟)، Magnetic Resonance Imaging وزن اصطلاح (؟)، Pediatrics

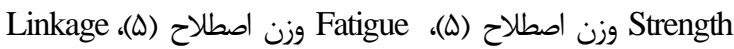
Analysis Pontocerebellar Hypoplasia وزن اصطلاح (fung Function وزن اصطلاح (r)، Body Composition وزن اصطلاح (r). خوشه شماره r شامل ·r اصطلاح مىباشد. اين اصطلاحات به

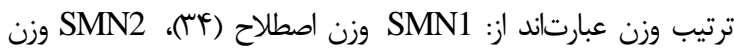
اصطلاح (Yr)، Survival Motor Neuron Gene وزن اصطلاح (YT)، Prenatal Diagnosis Neuronal Apoptosis Inhibitory Protein (NAIP) اصطلاح (1)، Polymerase Chain Reaction وزن اصطلاح (1))، وزن اصطلاح (ז)، GMN1 Gene

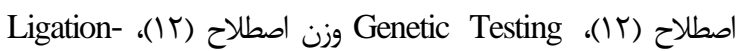
((1) Dependent Probe Amplification Mlpa مusinersen (•) (1)، وزن اصطلاح (9)، (9ene Deletional Apoptosis Gene، Inhibitory Protein (NAIP) Gene Dosage (9) Preimplantation Genetic Diagnosis 
Zebrafish Cystic Fibrosis

\section{بحث و نتيجه}

نتايج يزوهش نشان داد در حوزه SMA ده خوشه موضوعى تشكيل كَريد. خوشه شماره يك با مب عضو بزركترين خوشه اين حوزه است. بيشترين تمركز متون مورد مطالعه در حوزه بيمارى آتروفى عضلانى-

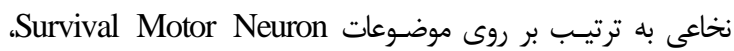
Motor ،Amyotrophic Lateral Sclerosis (ALS) SMN SMN1 , Motor Neurons (MNS) Neuron Disease (MND) مىباشد؛ كه نشان از اهميت اين مباحث در حوزه SMA دارد. بيمارى آتروفى عضلاىى نخاعى به دليل جهش در زن SMN1 به وجود مي آيد [YY]

علت رخداد اصطلاح ALS را مىتوان به اين شكل تفسير نمود اسكلروز جانبى آميوتروفيك (ALS) كه بيمارى نورون حركتى هم ناميده مىشود، يك بيمارى كشنده با ناتوانى به شدت (MND) يِيشرونده است، به دليل اينكه تاكنون هيج درمان قطعى براى آن وجود ندارد. رزيمهاى درمانى حال حاضر، براى بهبود كيفيت زندگى اين بيماران، فقط روى كاهش علائم متمركز هستند. براساس اطلاعات حاصل از مطالعات ييشباليانى، درمان سلولى، درمانى نويدبخش براى [raLS/MND

يكى بيمارى عصبى ماهيجֶهاى بِيش رونده است كه از مهمترين مشخصات آن تخريب نورونهاى حركتى در سيستم عصبى مركزى و محيطى است. در حال حاضر هيج روش كلينيكى دقيقى براى تشخيص ايسن بيمـارى ارائه نشده است. در اغلب موارد افراد داراى ALS به دليل اختلالات موجود در سيستم عصبى نمىتوانند به صورت عـادى راه بروند. به همين دليل، يكى از روشهاى مفيد براى تشخيص اين بيمارى از ساير بيمارىهـاى عصبى و يـا تـشخيص بيماران مبتلا به ALS مطالعات انجام شده، نـرخ شـيقع ايـن بيمارى ينج نفر در هر صد هـزار نفـر اسـت. در ايـن بيمـارى نورونهاى حركتى بالارونده و يإيينرونده،

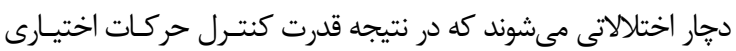
بـد توسط بيمار كاهش مى يابد [YV]
Expression

(V) Tوزن اصطلاح Transcription خوشه شماره 9 شامل • 1 اصطلاح مىباشد. اين اصطلاحات به ترتيب وزن عبارتاند از: Survival Motor Neuron (SMN) وزن Small Nuclear Ribonucleoprotein (SNRNP)، اصطلاح (r/) وزن اصطلاح (YY)، Cajal Body وزن اصطلاح (IV)، Gems وزن اصطلاح (ه) (1)، Animal Model وزن اصطلاح (I)، Drosophila وزن اصطلاح (rا)، Coilin وزن اصطلاح (•)، Gemin وزن اصطلاح (•) (1)، Nucleolus وزن اصطلاح (9)، Tudor Domain وزن اصطلاح

خوشه شماره V شامل •1 اصطلاح مىباشد. اين اصطلاحات به ترتيب وزن عبارتاند از: Apoptosis وزن اصطلاح (آ)، Survival Spinal Motor Neuron (SMN) Protein Cord وزن اصطلاح (צkeletal Muscle وزن)، وزطلاح (1)، Denervation وزBCL وزن اصطلاح (^)، Autophagy وزن اصطلاح (^)، Oxidative Stress وزن اصطلاح (N)، Induced Pluripotent Stem Cell (IPSC) وزن اصطلاح (9). خوشه شماره ^ شامل 9 اصطلاح مىباشد. اين اصطلاحات به ترتيب وزن عبارتاند از: Amyotrophic Lateral Sclerosis (ALS) وزن

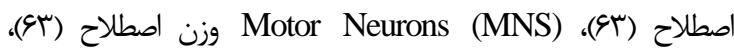

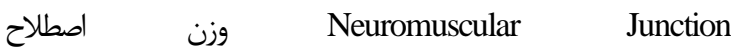
Axonal Transport وزن (Yq) Neurodegeneration (Y (Y) وزن اصطلاح (V)، Axonopathy وزن اصطلاح(V)، Axon وزن اصطلاح (؟)، Local Translation وزن اصطلاح (؟)، Synapse وزن اصطلاح (9). خوشه شماره 9 شامل V اصطلاح مىباشد. اين اصطلاحات به ترتيب وزن عبارتاند از: Proteomics وزن اصطلاح (ها)، Biomarker وزن اصطلاح (1)، Screening وزن اصطلاح (1)، Cell Death وزن صطلاح (•) Diagnosis وزن اصطلاح (•) Prognosis وزن

اصطلاح (^)، Lower Motor Neuron Disease وزن اصطلاح (V). خوشه شماره • ا شامل 9 اصطلاح مىباشد. اين اصطلاحات به ترتيب وزن عبارتاند از: Splicing وزن اصطلاح (وץ)، Ease Dis وزن اصطلاح (T) Monomelic Amyotrophy وزن اصطلاح (N)، 
براساس نتايج يزوهش ييشنهاد مى

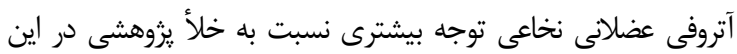
حوزه داشته باشند. سياست گذاران مباحث موضوعى داغ در اين حوزه را مورد توجه قرار دهند. همجنين حوزههاى نوظهور شناسايى شده در اين يزوهش، توسط يزوهشكران حوزه بيمارى آتروفى عضلانى نخاعى مورد بررسى قرار گيرند و آنها را جزو اولويتهاى يزوهشى اين حوزه قرار دهند. در پايان براى يزوهشهاى آتى پِيشنهاد مىشود كه وضعيت حوزه

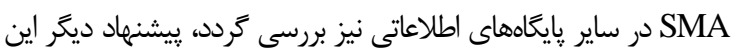
است كه اين حوزه با استفاده از ساير روشهاى علمسنجى نظير تحليل استنادى و هم تأليفى نيز مورد بررسى قرار گيرد.

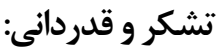
از متخصصان موضوعى حوزه بيمارى آتروفى عضلانى نخاعى كه در شناسايى هرجه بهتر خوشههاى موضوعى يارى مى تأييديه اخلاقى:

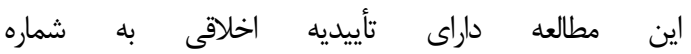
IR.MUMS.REC.1399.109 از دانشكاه علوم يزشكى هرمزكان است.

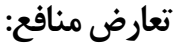

انجام اين مطالعه براى هيجيك از محققان هيجگونه تعارض و تضاد

$$
\text { منافعى نداشته است. }
$$

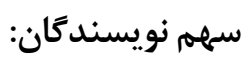

سهمم نويسندكان به ترتيب ذكر نام در مقاله سميرا دانيالى (نويسنده اول) تنظيم يرويوزال، طراحى يزوهش، ترسيم نقشه (•ه درصد)، نصرت

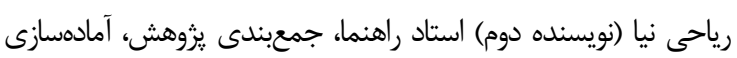
نهايى يروهش (•r درصد)، سميه قويدل (نويسنده سوم) كردآورى

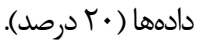

\section{حمايت مالى:}

اين مقاله از طرف هيجَّونه نهاد يا موسسهاى حمايت مالى نشده و تمام منابع مالى آن از طرف نويسندًان تأمين شده است.
به صورت كلى ALS يك بيمارى بيشرونده و ناتوانكننده است و

شايعترين بيمـارى موتـور نـورون مىباشد. ويزگگى خاص اين بيمارى همزمان بـودن علائم Lower Motor Neuron وUpper است. بسيارى از موارد ALS بـا علائمم Lower Motor Neuron (LMN) شـروع مىشود و بعـد دركيـرى Upper Motor Neuron اضافه مى

همجنين، كوجكى دايرهاى Lower Motor Neuron Disease كه مربوط به نورون محركه تحتانى است و Gene Expression كه مربوط به بيان ثن است و Exonic Splicingenhancer در نقشه همرخدادى نشان از فقر مقالات علمى در اين حوزهها دارد كه نياز به توجه بيشتر به اين مباحث را مى طلبد.

در نقشه همرخدادى وازَّان حوزه SMA، فاصله مفاهيم از هم در سطح نقشه كم است و اين نشاندهنده ارتباط زياد مفاهيم با يكديكر است. بلبيانديكر، تراكم حوزههاى موضوعى يا توصيفكرها در مقالات زياد است. در اين نقشه، مفاهيم هركدام يك گره هستند و اين يافته در راستاى نتايج يزوهش Yang و همكاران است [Y]]. از آنجا كه كشف الكوهاى ارتباطى بين موجوديتها از اهداف ديدارىسازى به شمار مىآيد انتظار مىرود كه اين نقشهها به كاربر اين امكان را بدهند تا روابط ميان عناصر را كشف كنند. در اين نقشهها عناصر مرتبط با يكديگر در مجاورت هم و عناصر متفاوت دورتر از يكديگر قرار

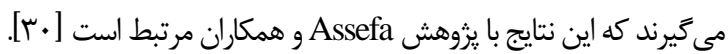
نتايج مطالعات صديقى در حوزه موضوعى اطلاعسنجى و مكىزاده و همكاران در حوزه تحليل موضوعى درمان افسردىى حاكى از آن بود كه ساختار مقولههاى موضوعى در اين دو حوزه، در طول زمان تغيير كرده و به صورتى يويا گسترش يافته است كه با يافتههاى بررسى حاضر مشابهت داشت. كاربران و سياستگذاران حوزه SMA از طريق نقشه علم اين حوزه مىتواند، ديدى جامع نسبت به ساختار اين حوزه در سطح بينالمللى پيدا كنند، با موضوعات اصلى، داغ و حاشيداى اين حوزه در سطح بين المللى آشنا شوند [9] با آكاهى از وزن/ جكالى اصطلاحات و نحوه ارتباط اصطلاحات مىتوان ارتباط موضوعى اصطلاحات و اهميت هر گره را كثف نمود. نقشه علم حوزه SMA اين امكان را مىدهد كه بتوان كل ساختار اين حوزه را در يك صفحه مشاهده نمود و رنخهاى مختلف اختصاص داده شده به هر خوشه سبب تسهيل تشخيص خوشههاى موضوعى و اصطلاحات هر خوشه خواهد شد. 
1. Makkizade F, Tavakolizade Ravari M, Dana M, Soheili F. A survey on the statues of global warming phenomenon domain and drawing scientific maps of this domain in Iran. Rahyaft 2016; 26(61):75-88. [In Persian]

2. Zilfalil BA, Zabidi-Hussin AM, Watihayati MS, Rozainah MY, Naing L, Sutomo R, et al. Analysis of the survival motor neuron and neuronal apoptosis inhibitory protein genes in Malay patients with spinal muscular atrophy. Med J Malaysia. 2004; 59(4):512-4.

3. Panigrahi I, Kesari A, Phadke SR, Mittal B. Clinical and molecular diagnosis of spinal muscular atrophy. Neurol India. 2002; 50(2):117-22.

4. Velasco E, Valero C, Valero A, Moreno F, Hernández-Chico C. Molecular analysis of the SMN and NAIP genes in Spanish spinal muscular atrophy (SMA) families and correlation between number of copies of cBCD541 and SMA phenotype. Hum Mol Genet. 1996; 5(2):257-63. DOI: 10.1093/hmg/5.2.257

5. Lefebvre S, Bürglen L, Reboullet S, Clermont $\mathrm{O}$, Burlet $\mathrm{P}$, Viollet L, et al. Identification and characterization of a spinal muscular atrophydetermining gene. Cell. 1995; 80(1):155-65 . DOI: 10.1016/0092-8674(95)90460-3

6. Burglen L, Seroz T, Miniou P, Lefebvre S, Burlet $\mathrm{P}$, Munnich A, et al. The gene encoding p44, a subunit of the transcription factor TFIIH, is involved in large-scale deletions associated with Werdnig-Hoffmann disease. Am J Hum Genet. 1997; 60(1):72-9. PMID: 8981949

7. Bauin S. Aquaculture: A Field by Bureaucratic Fiat. In: Callon M, Law J, Rip A, editors. Mapping the dynamics of science and technology: Sociology of science in the real world. London: Palgrave Macmillan; 1986. DOI: 10.1007/978-1-349-07408-2_8

8. Brown T, Glanzel W, Schubert A. Scientometrics indicators, comparative evaluation of publishing activities and impact of country references. Translated by: Riahi ME. Rahyaft. 1996; 4(7):1-5. [In Persian]

9. Sedighi M. Using of co-word analysis method in mapping of the structure of scientifc felds (Case study: The field of informetrics). JIPM. 2015; 30(2):373-96. [In Persian]
10. Mehdizadeh Maraghi R, Nazari M, Minaii MB. Mapping science of massage therapy during 2008-2013 in the Scopus database. JIITM. 2014; 4(4):333-42. [In Persian]

11. Ahmadi H, Kokabi M. Co-word analysis: A study on the links and boundaries between information and knowledge management according to Iranian press authors. JIPM. 2015; 30(3):646-76 .[In Persian]

12. Zolfaghari S, Soheili F, Tavakolizadeh Ravari M, Mirzaee A. A Patents' co-word analysis for determining the subject trends of technology. Rahyaft. 2015; 25(59):51-65. [In Persian]

13. Makkizadeh F, Hazeri A, Hosininasab S, Soheili F. Thematic analysis and scientific mapping of papers related to depression therapy in PubMed. JHA. 2016; 19(65):51-63. [In Persian]

14. Khademi R, Heidari G. Mapping the intellectual structure of information management using co-words during 1986 to 2012. Sciences and Techniques of Information Management. 2016; 2(2):59-93. [In Persian] DOI: $10.22091 /$ stim.2016.717

15. Mostafavi I, Osareh F, Tavakkolizadeh Ravari M. Analysis on the structure of KIS scientific words and concepts based on social network analysis in the "Web of Science" database (1993-1997 and 2009-2013). Research on Information Science \& Public Libraries. 2017; 23(2):237-64. [In Persian]

16. Mozaffari L, Moradi S. Comprehensive analysis of vocabulary in the field of communication skills. In: Library and Information Society of Iran, editors. Proceedings of the Perspectives of Scientific Communication, of the 2th national conference of the library and information society of Iran; 2019 May 9-10; Shiraz, Iran; 2019. P105-16. [In Persian]

17. Zong QJ, Shen HZ, Yuan QJ. Hu XW, Hou ZP, Deng SG. Doctoral dissertations of library and information science in China: A co-word analysis. Scientometrics. 2013; 94(2):781-99. DOI: 10.1007/s11192-012-0799-1

18. Xie Y. Hotspots of ecological and environmental rise research in china based on co-word analysis. Information \& Computational Science. 2014; 11(4):1185-92. DOI: $10.12733 /$ jics 20103065 
19. Hou Q, Mao G, Zhao L, Du H. Mapping the scientific research on life cycle assessment: A bibliometric analysis. Int J Life Cycle Assess. 2015; 20:541-55. DOI: 10.1007/s11367-0150846-2

20. Chen G, Xiao L, Hu CP, Zhao XQ. Identifying the research focus of library and information science institutions in China with institutionspecific keywords. Scientometrics. 2015; 103(2):707-24. DOI: 10.1007/s11192-015$1545-2$

21. Konstantinidis ST, Billis A, Wharrad $\mathrm{H}$, Bamidis PD. Internet of things in health trends through bibliometrics and text mining. In: Randell R, Cornet R, McCowan C, Peek N, Scott P, editors. Informatics for health: Connected citizen-led wellness and population health. Amsterdam, Netherlands: IOS Press; 2017. P73-7. DOI: 10.3233/978-1-61499-7535-73

22. Khasseh AA, Soheili F, Sharif Moghaddam H. Mousavi Chelak A. Intellectual structure of knowledge of imetrics: A co- word analysis. Inf Process Manag. 2017; 53(3):705-20. DOI: 10.1016/j.ipm.2017.02.001

23. Noyon ED. Bibliometric mapping of science in a science policy context. Scientometrics. 2001; 50(1):83-98. DOI: 10.1023/A:1005694202977

24. Brzustowicz LM, Lehner T, Castilla LH, Penchaszadeh GK, Wilhelmsen KC, Daniels $\mathrm{R}$, et al. Genetic mapping of chronic childhood-onset spinal muscular atrophy to chromosome 5q1 1.2-13.3. Nature. 1990; 344(6266):540-1. DOI: 10.1038/344540a0
25. Wahid SFA, Law ZK, Ismail NA, Azman Ali R, Lai NM. Cell-based therapies for amyotrophic lateral sclerosis/motor neuron disease. Cochrane Database Syst Rev. 2016; 11:CD011742 DOI: 10.1002/14651858.CD011742.pub2

26. Abedi B, Abbasi A, Sarbaz Y, Goshvarpour A. Early detection of amyotrophic lateral sclerosis (ALS) using the gait motor signal frequency analysis. J Arak Uni Med Sci. 2016; 19(3):5461. [In Persian]

27. Nijboer F, Broermann U. Brain-Computer Interfaces for communication and control in locked-in patients. In: Graimann B, Pfurtscheller G, Allison B, editors. Braincomputer interfaces: Revolutionizing humancomputer interaction. Berlin: Springer; 2010. p. 185-202. DOI: 10.1007/978-3-642-020919_11

28. Bradly WG, Daroff RB, Fenichl GM, Jankovic J. Neurology in clinical practice; Volume 1.5th ed. Philadelphia: Butterworth-Heinemann, Elsevier; 2008.

29. Yang YH, Bhikshu H, Tsaih RH. The topic analysis of hospice care research using co-word analysis and GHSOM. In: Chen R, editors. Intelligent computing and information science, (ICICIS). Chongqing, China; 2011. DOI: 10.1007/978-3-642-18129-0_72

30. Assefa, SG, Rorissa A. A bibliometric mapping of the structure of STEM education using co-word analysis. J Am Soc Inf Sci Technol. 2013; 64(12):2513-36. DOI: 10.1002/asi.22917 


\title{
Drawing word co-occurrence map of spinal muscular atrophy disease
}

\author{
Samira Daniali $^{{ }^{*}} \quad$ Nosrat Riahi Nia ${ }^{2} \quad$ Somayeh Ghavidel $^{3}$
}

1. Department of Knowledge and Information Science, School of Psychology and Educational Sciences, Kharazmi University, Tehran, Iran. ORCID: 0000-0002-6941-360X

2. PhD, Knowledge and Information Science, School of Psychology and Educational Sciences, Kharazmi University, Tehran, Iran.

3. PhD Student, Knowledge and Information Science, School of Psychology and Educational Sciences, Kharazmi University, Tehran, Iran.

(Received 13 May, 2020

Accepted 31 Aug, 2020)

\section{Original Article}

\begin{abstract}
Aim: The purpose of this article is to evaluate the status of the articles in the field of Spinal Muscular Atrophy based on scientometric indices and to draw a co-occurrence map of words in this field.

Methods: This quantitative descriptive study has been done by using scientometrics and the co-occurrence words analysis techniques. Documentary or library studies have been used to get acquainted with the history of the subject and the theoretical foundations of the research. In this study, 4137 scientific products in the field of spinal muscular atrophy diseasewere studied in the Web of Science database (1946-2018). VSO Viewer and Excel software were used to analyze and draw the co-occurrence map of words.
\end{abstract}

Results: In the field of Spinal Muscular Atrophy, ten clusters were formed.Cluster number one with 38 members is the largest cluster in this field. The most focused texts in the field of Spinal Muscular Atrophy are Survival Motor Neuron (SMN), Amyotrophic Lateral Sclerosis (ALS), Motor Neuron Disease (MND), Motor Neurons (MNS) and SMN1, respectively. Also, the small number of subjects of Lower Motor Neuron Disease, Gene Expression, Exonic Splicing Enhancer in the coherent map shows the lack of scientific articles in these fields.

Conclusion: conducting such a study in the field of Spinal Muscular Atrophy can play an essential role in future policies of this field and properly highlight research gaps and hot topics.

Key Words: Co-Occurrence Words Map, Scientometrics, Muscular Atrophy Disease Disease, Science Map.

Citation: Daniali S, Riahi Nia N, Ghavidel S. Drawing word co-occurrence map of spinal muscular atrophy disease. J Mod Med Info Sci. 2020; 6(2):11-21.

\footnotetext{
Correspondence:

Samira Daniali

Department of Knowledge and Information Science, School of Psychology and Educational Sciences, Kharazmi University, Tehran, Iran.

Tel: +9354333792Ｅmail: s.danialy89@gmail.comＯRCID.0000-0002-6941-360X
}

مجله اطلاعرسانى بزشكى نوين، دوره ششم، شماره دوم، تابستان 99 11 